\title{
Improving students anecdot writing ability through genius learning strategies and discussion methods
}

\author{
Vivi Maria ${ }^{1}$, Missriani $^{2}$, Yessi Fitriani ${ }^{3}$ \\ ${ }^{1}$ Sekolah Menengah Atas Negeri 4 OKU, Indonesia \\ ${ }^{2}$ Universitas PGRI Palembang, Indonesia
}

\section{Article Info \\ Article history: \\ Received Jul 22 $2^{\text {th }}, 2021$ \\ Revised Aug $15^{\mathrm{h}}, 2021$ \\ Accepted Aug 30 $0^{\text {th }}, 2021$}

\section{Keyword:}

Anecdote Writing

Genius Learning Strategy

Lecture Method

\begin{abstract}
The purpose of this study was to improve the ability of class X IPS 1 SMA Negeri 4 OKU through genius learning strategies and lecture methods. Research data collection techniques using observation, documentation and tests. The research data analysis technique used a descriptive writing test through direct learning and observation models to see student learning activity. Based on the results of the study, it can be concluded that there is an increase in the ability to write anecdotes through genius learning strategies and lecture methods in class X IPA 1 SMA Negeri 4 OKU. In cycle 1 , an average value of 66.68 was obtained, students who achieved completeness were 22 students or the percentage of completeness was $61.11 \%$. In cycle 2 the average value is $69.28 \%$. Students who achieved completeness were 29 students or the average persetanse completeness was $80.56 \%$. Furthermore, in cycle 3 the average value is 76.81 . Students who achieved completeness were 34 students or the percentage of student completeness was $94.44 \%$.
\end{abstract}

C 2021 The Authors. Published by IICET.

This is an open access article under the CC BY-NC-SA license

(https://creativecommons.org/licenses/by-nc-sa/4.0

\section{Corresponding Author:}

Maria, V.,

Sekolah Menengah Atas Negeri 4 OKU, Indonesia

Email: mariavivi239@gmail.com

\section{Introduction}

In essence, the main function of language is as a means of communication. Therefore, learning Indonesian language and literature is directed so that students are skilled at communicating, both oral and written. Learning Indonesian Language and Literature must be directed at the essence of Indonesian Language and Literature as a means of communication. As it is known that now language learning is changing, from an emphasis on learning the form aspects to learning which emphasizes the aspects of function. Generally, the information obtained from reading can have an effect on increasing knowledge and skills.

Writing as a language skill is recognized by the public. Writing is a skill that requires good language mastery. In language learning, writing is an advanced skill. [1] argues that teaching writing is the basis for writing skills. So it is clear here that reading is very beneficial for the improvement of one's intellectual, manner and character. Another opinion says that reading is a process that is carried out and used by readers to get the message the writer wants to convey through the media of words or written language [2].

Regarding writing in Indonesian language learning at SMA Negeri 4 OKU, especially students of class X IPS 1 on the subject of writing anecdotes. In the learning process students do not understand the material presented, teaching and learning activities become inactive, not creative because the learning material is given using the ordinary lecture method, meaning that it only explains in general terms to students without using the 
aid of visual media and giving assignments, so the results who are expected to have not reached the specified KKM. The results of daily tests in writing anecdotes for class X IPS 1 SMA Negeri 4 OKU only reached a score of 53 (KKM.70). Complete learning as many as 9 students or $25 \%$ of the 36 existing students, and 27 students or $75 \%$ have not reached the completeness of student learning in writing anecdotes.

Based on the description of some of the factors that led to the incomplete learning of classical writing anecdotes, the researcher felt the need to make changes in the learning by using genius learning strategies and lecture methods to emphasize class X IPS 1 students at SMA Negeri 4 OKU. Researchers saw several advantages of the genius learning strategy in Indonesian language learning in the subject of writing anecdotes, as stated by [3] which states that each strategy or learning model must have advantages and disadvantages.

The advantages of this genius learning include:(1)Genius Learning really appreciates the differences in intelligence possessed by each individual;(2)Genius Learning invites teachers to be broad-minded, this is because the more knowledge the teacher has, the easier it will be for teachers to optimize the learning process;(3)Genius Learning really appreciates the differences in learning styles of each student, so that teachers can find the right solution in finding appropriate learning methods;(4)Genius Learning really appreciates and considers the environment and society involved in the learning process;(5) Genius Learning is a learning strategy that makes students the subject of learning.

In addition, some of the advantages of learning using the lecture method, as suggested by [4] are as follows:(1)The lecture method is an inexpensive and easy method, which means that lectures do not require complete equipment, whereas it is easy because lectures only rely on the voice of the teacher and do not require complicated preparation;(2)The lecture method can present a broad subject matter, meaning that many subject matter can be explained only by the teacher;(3)The lecture method can provide material points that need to be highlighted, meaning that the teacher can arrange the subject matter that needs to be emphasized according to the needs and goals to be achieved;(4)Through lectures the teacher can control the state of the class, because the class is the responsibility of the teacher who lectures;(5)Class organization using lectures can be simplified.

Seeing the fact that occurs in the learning process of writing anecdotes stated above, it is a reason for researchers to conduct research with the title of increasing the ability to write anecdotes through genius learning strategies and lecture methods in class X IPS 1 SMA Negeri 4 OKU. Another reason the study wanted to study using the genius learning strategy and lecture method the researcher believed that through the use of these strategies and methods was able to improve the ability to write anecdotes in class X IPS 1 SMA Negeri $4 \mathrm{OKU}$ worthy of research.This study aims to determine and describe the process of increasing the ability to write anecdotes through genius learning strategies and lecture methods for class X IPS 1 students at SMA Negeri 4 OKU.

Based on [5] ability comes from the word "able" which means power (can, be able, do something, can, have excessive assets). Ability is the ability to do something. Someone is said to be capable if he does not do something he has to do.

According to Halim (2014:35), writing skills are the skills to organize and express the following elements: (1) content of essays, (2) form of essays, (3) grammar, (4) style or choice of structure and vocabulary, and (5) application of spelling and use of punctuation marks.

In principle, the main purpose of writing is an indirect community. Writing is very important for education because it makes it easier for students to think. Helping us think critically, feel and enjoy relationships, deepen our responsiveness or perception, solve the problems we face, and arrange a sequence for experiences [6]. From this opinion, it is clearly reflected in the importance of writing skills for everyone, especially for students.

In principle, the main purpose of writing is an indirect community. Writing is very important for education because it makes it easier for students to think. Helping us think critically, feel and enjoy relationships, deepen our responsiveness or perception, solve the problems we face, and arrange a sequence for experiences [6]. From this opinion, it is clearly reflected in the importance of writing skills for everyone, especially for students.

[2] states that, "Writing is a very powerful tool in learning, which in itself plays a very important role in the world of education". Seen from this point of view, suggesting the usefulness of writing in detail as follows. a) Writing monologues rediscovered what was once known. Writing about a topic stimulates the reader's thinking about that topic and helps us generate knowledge and experiences stored in the subconscious. b) Writing generates new ideas. The act of writing stimulates the mind to seek connections, and draws equations (analogies) that would not have happened had writing not started. c) Writing helps organize thoughts and put them in a form that stands alone, just because of writing. d) Writing makes one's mind ready to be seen and evaluated; can distance themselves from their own ideas and view them more objectively at the time of 
writing. e) Writing helps to absorb and master new information, it will be understood much better by being delivered longer if written about it. f) Writing helps solve problems by clarifying the elements and placing them in a visual context so that they can be tested. g) Writing about a topic makes a student active.

\section{Method}

Observation in this action research is to make observations during the learning process. Observations were made during the learning to write anecdotes through the genius learning strategy and the lecture method for class X IPS 1 SMA Negeri 4 OKU to see developments before and after the action was taken. The use of this genius learning strategy in the learning process of writing anecdotes can be used as material for solving student problems in everyday life in the real world which can be used as study material in this study with the aim of solving student problems in understanding any learning material presented.

The documentation used as data collection material in this study is in the form of observation sheets, such as observation sheets of student activeness in learning to write anecdotes through genius learning strategies and lecture methods in class X IPS 1 SMA Negeri 4 OKU, student test scores in learning activities. writing anecdotes through genius learning strategies and lecture methods in class X IPS 1 SMA Negeri 4 OKU. Besides that, other supporting documentation data is in the form of research photos, research permits in order to complement the research data.

The test in this study, the researcher gave a test on each cycle, both the first cycle and the next cycle in order to determine the ability to write anecdotes through genius learning strategies and lecture methods in class X IPS 1 SMA Negeri 4 OKU. The results of the learning process are guided by the KKM by referring to the percentage increase in each cycle.

\section{Results and Discussions}

Based on the research findings, the improvement of anecdotal writing skills through genius learning strategies and lecture methods in class X IPS 1 SMA Negeri 4 OKU in each cycle, it is illustrated that there is an increase in each cycle. The results of the research findings in cycle 1 obtained an average ability to write anecdotes through genius learning strategies and lecture methods in class X IPS 1 SMA Negeri 4 OKU on the material "Increase in fuel prices" of 66.68 , students who achieved completeness were 22 students. or the percentage of completeness is $61.11 \%$. In cycle 2 there was an increase in the ability to write anecdotes through genius learning strategies and lecture methods in class X IPS 1 SMA Negeri 4 OKU, which was an average of 69.28. Students who achieved completeness were 29 students or the average persetanse completeness was $80.56 \%$. Furthermore, in cycle 3 there was an increase again, namely the average ability to write anecdotes through genius learning strategies and lecture methods in class X IPS 1 SMA Negeri 4 OKU obtained a value of 76.81 . Students who achieved completeness were 34 students or the percentage of student completeness was $94.44 \%$.

Sometimes however we give reprimands and directions, these students only pay attention for a moment, but the next minute they still repeat them. However, the author tries to provide the best for students in the process of learning to write anecdotes through genius learning strategies and lecture methods in class X IPS 1 SMA Negeri $4 \mathrm{OKU}$ with various strategies. This refers to the findings in cycle 1 and cycle 2 , where the material provided in cycle 1 is "Increase in Fuel Prices", then the material given in cycle 2 is "Pandemic Covid 19", then the author uses other material in cycle 3, namely the "Job Creation Bill" by using in-focus and collaborating with the lecture method. The author focuses on students who do not pay attention or students who often chat while learning is taking place, namely writing anecdotes through genius learning strategies and lecture methods in class X IPS 1 SMA Negeri 4 OKU.

Evidenced in this way, activeness in anecdotal learning through genius learning strategies and lecture methods in class X IPS 1 SMA Negeri 4 OKU has increased. Students who were previously involved passively become actively involved, students who are not involved become actively involved. It turns out that the improvements applied in learning to write anecdotes through the genius learning strategy and the lecture method for class X IPS 1 SMA Negeri 4 OKU resulted in good improvements. All students pay close attention, and students better understand the material presented, especially regarding the material "Job Creation Bill" as research material. Students are very enthusiastic in understanding the material, because the material on the Job Creation Bill is material that is currently viral. 
Based on theoretical studies, it also supports this research, that writing as a language skill is recognized by the public. Writing is a skill that requires good language mastery. In language learning, writing is an advanced skill. Semi (2012: 5) argues that teaching writing is the basis for writing skills. So it is clear here that reading is very beneficial for the improvement of one's intellectual, manner and character. Another opinion says that reading is a process that is carried out and used by readers to get the message the writer wants to convey through the media of words or written language (Dalman, 2014: 7). Writing as a language skill requires someone's expertise in using written language for communication purposes. Therefore, writing skills must involve a variety of skills, namely: (1) skills to express ideas or ideas, (2) skills in organizing these ideas or ideas, (3) skills to apply grammatical and syntactic patterns, and (4) choosing skills structure and vocabulary.

\section{Conclusions}

Based on the results of the study, it can be concluded that there is an increase in the ability to write anecdotes through the genius learning strategy and the lecture method in class X IPS 1 SMA Negeri 4 OKU. In cycle 1, an average value of 66.68 was obtained, students who achieved completeness were 22 students or the percentage of completeness was $61.11 \%$. In cycle 2 the average value is $69.28 \%$. Students who achieved completeness were 29 students or the average persetanse of completeness was $80.56 \%$. Furthermore, in cycle 3 the average value is 76.81 . Students who achieved completeness were 34 students or the percentage of student completeness was $94.44 \%$. Writing as a language skill requires someone's expertise in using written language for communication purposes. Therefore, writing skills must involve a variety of skills, namely: (1) skills to express ideas or ideas, (2) skills to organize ideas or ideas just by the teacher; (3) The lecture method can provide material points that need to be highlighted, meaning that the teacher can arrange the subject matter that needs to be emphasized according to the needs and goals to be achieved; (4) Through lectures the teacher can control the state of the class, because class is the responsibility of the teacher who lectures; (5) Class organization using lectures can be simplified.

\section{References}

Semi, Atar. 2012. Dasar-Dasar Keterampilan Menulis. Bandung: Angkasa.

Dalman. 2014. Keterampilan Dasar Menulis. Jakarta: Rineka Cipta

[Trianto. 2014. Model-Model Pembelajaran. Jakarta: Rineka Cipta

Trianto. 2014. Model-Model Pembelajaran. Jakarta: Rineka Cipta

Sanjaya, Wina. 2014. Strategi Pembelajaran Berorientasi Standar Proses Pendidikan. Jakarta: Kencana Prenada Media Group.

Kamus Besar Basar Indonesia 2013. Pengertian Menulis. Jakarta: Balai Pustaka, Pusat Kajian Bahasa.

Tarigan, Henry Guntur. 2012. Menulis Sebagai Suatu Keterampilan Berbahasa. Bandung: Angkasa. 